\title{
Aikuiskasvatuksen erityisongelmia yhdentyvässä Euroopassa
}

\section{Aikuisten työpaikka- ja}

työllisyyskoulutus on nopeasti

lisääntymässä. Ollakseen

kilpailukykyisiä eri maiden on

varmistuttava siitä, että niiden

työvoima kykenee sopeutumaan

muuttuviin vaatimuksiin, suorittamaan monenlaisia tehtäviä, ylittämään ammatilliset rajat, ymmärtämään yrityksen laajemmat tavoitteet ja hankkimaan uusia tietoja ja taitoja. Tämä edellyttää hyvin järjestettyä kansallista aikuiskoulutusjärjestelmää.

Eurooppalainen aikuiskoulutus kohtaa kuitenkin monia ongelmakohtia, joista suurin on huonoosaisten koulutus sekä koko Eurooppaa ajatellen pienten lasten äitien ja yksinhuoltajien paluu työelämään sekä ikääntyvien koulutus.

Artikkelissa pohdiskellaan myös yliopistojen aikuiskoulutusvastuuta.

Euroopalla on yhteinen kulttuuri. Sen perimmäinen sopeutuvuus on tullut ilmi siinä nopeudessa, jolla taloudellisia, sosiaalisia ja kulttuurisuhteita - kahdenvälisiä ja monenkeskisiä - on solmittu vuodesta 1990 alkaen idän ja lännen valtioiden välille. Kommunismi on kuollut, ja kaikki maat ilmoittavat nyt hyväksyvänsä vapaan markkinatalouden, toistensa kunnioittamisen ja yhteisymmärryksen periaatteen kansainvälisissä suhteissa, yksilön oikeuksien ja vapauksien huomioonottamisen ja uskon maailman järjestykseen.
Myös aikuiskasvatuksen alueella on yhteisiä arvoja ja intressejä. Lännessä johtavilla aikuiskasvattajilla on ollut läheiset suhteet toisesta maailmansodasta lähtien, joillakin jopa jo aikaisemmin. The European Bureau of Adult Education on ollut myötävaikuttamassa tähän. Eurooppalaiset olivat pääroolissa ensimmäisessä, Helsingörissä 1949 pidetyssä Aikuiskasvatuksen maailmankonferenssissa.

\section{Tiedon lähteitä}

Vuodesta 1976 lähtien European Centre for Leisure and Education (ECLE) on julkaissut huomattavan määrän vertailevia tutkimuksia ja maakohtaisia monografioita, jotka perustuvat joukolle yhteisiä indikaattoreita ja jotka koskevat itää ja länttä niitä erikseen erottelematta. Jos englantilainen aikuiskasvattaja haluaa tietää, miten aikuiskasvatus on organisoitu, rahoitettu ja toteutettu melkeinpä missä tahansa Euroopan maassa, hän voi tutustua asiaa käsittelevään ECLE:n tutkimukseen tai johonkin sellaisten asiantuntijoiden tutkimuksiin, kuten Knollin Saksasta, Besnardin Ranskasta tai Collin Titmusin Skotlannista. Saadakseen tietoa jostakin aikuiskasvatuksen teorian tai käytännön erityiskysymyksestä, riittää kun valitsee kyseisen hakusanan laajasta bibliografiasta, jota Jindra Kulich on toimittanut vuodesta 1971 lähtien (Adult Education in Continental Europe: an Annotated Bibliography of English Language Materials).

Informaation määrä eräistä maista on valtava. Esimerkiksi Tanskan ja Ruotsin aikuiskasvatuksesta on julkaistu runsaasti materiaalia englanniksi. Myös Hollannista ja Saksasta on runsaasti 
saatavissa tietoa. Entisestä Jugoslaviasta oli myös paljon tietoa, mutta se oli englantia lukevalle suurelta osin saavuttamattomissa niin filosofisista kuin kielellisistäkin syistä.

Myös konferensseja, seminaareja ja tutkijavierailuja on ollut runsaasti. Parin kymmenen vuoden aikana kansainvälisten tapahtumien määrä on lisääntynyt nopeasti. Avainkysymys onkin: onko kaikki tämä toiminta todella informatiivista? Jos hylkäämme ilkeämielisen ein, sen että kansainväliset tapahtumat yksinkertaisesti mahdollistavat matkustamisen toisten rahoilla, näyttäisi olevan kaksi huomionarvoista vastausta: ne auttavat edistämään eurooppalaista yhteisymmärrystä ja yhteistyötä, ja ne voivat kehittää osallistujia heidän omissa tehtävissään. Ne, jotka ovat vertailevan aikuiskasvatuksen asiantuntijoita, sekä monet korkeakoulujen täydennyskoulutuskeskusten johtajat saattavat myös sanoa, että kansainvälisiin kokouksiin osallistuminen on olennaista heidän erityistietämyksensä ja kriittisen ajattelun kehittämisen kannalta.

Lyhyesti sanoen, on suhteellisen helppoa hankkia lukemalla ja kokoustamalla yksinkertaista kuvailevaa tietoa eurooppalaisesta aikuiskasvatuksesta. Mutta syvällisen ja todella käyttökelpoisen tiedon hankkimisen tiellä on ainakin kolme estettä: 1. puutteellinen käsitys olosuhteista; 2 . ajan puute; 3 . riittämätön kieli(kielten)taito.

Olosuhteiden tuntemisella tarkoitan riittävää maan historian, maantieteellisten seikkojen, yhteiskunnan, talouden ja politiikan tuntemusta, jotta voi asettaa aikuiskasvatuksen mahdollisuudet järkeviin yhteyksiinsä. Mitä taas ajankäyttöön tulee, jotakin voidaan tietysti oppia osallistumalla kokouksiin tai opintomatkoille, mutta paljon vähemmän kuin tutustumalla paikan päällä aikuiskasvattajien ja -opiskelijoiden toimintaan ja viettämällä pitempiä aikoja tarkoin valikoiduissa kohteissa.

Mitä kielitaitoon tulee, vaikka englannilla selviääkin paremmin kuin muilla kielillä, ainakin Pohjoismaissa, siitä ei ole apua, jos haluaa päästä sisälle aikuiskasvatuksen käytäntöihin muissa Euroopan maissa. Esimerkiksi Espanjassa, jossa Francon hallituskauden jälkeen on tapahtunut monia tärkeitä uudistuksia kuten uudenlaisen avoimen yliopiston mallin kehittäminen, on tietoa saatavissa vain espanjan kielellä. Vaikka koulutusviranomaiset julkaisevatkin tärkeimmät raportit lisääntyvässä määrin myös englanniksi, on niitä vaikea ymmärtää, ellei ole omakohtaista kokemusta olosuhteista.

Lyhyessä tilassa ei ole mahdollista antaa tarkkaa ja yksityiskohtaista kuvausta kansallisista järjestelmistä. Siksi aionkin tarjota muutamia huomioita yleisistä trendeistä ja ongelmakohdista Euroopan aikuiskasvatuksessa sekä yliopistojen laajenevasta asemasta siinä. Osa siitä, mitä sanon, soveltuu koko Eurooppaan, mutta Itä- ja Keski-Eurooppaa koskevan ensikäden tiedon puuttuessa minun on viitattava pääasiassa läntisen Euroopan olosuhteisiin.

\section{AIKUISKASVATUKSEN KEHITYS- PIIRTEITÄ JA ONGEIMIA}

\section{Aikuiskasvatuksen välttämättömyys}

Kansalliset asiantuntijat kaikkialla Euroopassa ovat laajasti julistaneet aikuiskasvatuksen ja elinikäisen oppimisen välttämättömyyttä syistä, jotka ovat tunnettuja kaikille alalla toimiville.

1) Aivan kuten jokaisella lapsella on ollut 1800luvulta lähtien oikeus peruskoulutukseen, tulisi nykyaikana jokaisella aikuisella olla oikeus täydentää koulutustaan vastaavalla tavalla.

2) Modernin talouselämän tulee kehittää inhimilliset voimavaransa täyteen mittaansa. Ei riitä, että vain nuorista koulutetaan tuottavaa työvoimaa. On pikemminkin kohotettava aikuisen työvoiman tuottavuutta nostamalla koko väestön koulutustasoa.

3) Tietyt oppiaineet ja asiat opitaan parhaiten myöhemmällä iällä, kun ihmiset voivat käyttää hyväksi kokemustaan ja iän mukanaan tuomaa kypsyneisyyttään.

4) Naisten kouluttaminen on aikaisemmin laiminlyöty. (Ei koske Pohjoismaita, joissa naisten osuus niin perus-, yliopisto- kuin aikuiskoulutuksessakin on korkea; suomentajan huomau- 
tus) Sekä sosiaalinen oikeudenmukaisuus että tarpeellisten kykyjen tuhlaamisesta luopuminen vaativat laiminlyönnin lopettamista. Sukupuolisyrjinnän vuoksi monet naiset eivät ole toistaiseksi voineet hyötyä peruskoulun jälkeisestä koulutuksesta; jotkut ovat niin tehneet, mutta ovat huomanneet uransa jääneen lyhyeksi avioliiton ja äitinä olemisen vuoksi. Vasta äskettäin on tunnustettu, että ura- ja työskentelymahdollisuuksien laajentaminen koskemaan myös naisia on arvokasta sekä talouden että yhteiskunnan yleisen hyvinvoinnin kannalta.

Poliittiset toimenpiteet ovat toistaiseksi vastanneet useimmissa maissa huonosti aikuiskasvatuksen välttämättömyyttä vakuuttelevaa julkista retoriikkaa, vaikka aikuiskasvatuksen toteuttamismenetelmiä - erityisesti jatkuvan koulutuksen strategia - onkin suunniteltu. Ruotsi on loistava poikkeus. (Suomen ja Ruotsin tilanne on samankaltainen. Kirjoittaja ei ilmeisestikään tunne Suomen aikuiskasvatusta; suomentajan huomautus) Voidaan kuitenkin ennustaa, että seuraavien kolmen tekijän vaikutuksesta hallitusten ja yhteiskuntien on ryhdyttävä paljon positiivisempiin toimiin kehittääkseen ja vastatakseen aikuisten opiskelutarpeisiin tulevaisuudessa:

1) kansainvälinen taloudellinen kilpailu ja tarve maksimoida inhimillisten voimavarojen käyttö;

2) työvoimapula kansantalouden avainaloilla; ja

3) väestön ikäryhmittäinen uusjako.

\section{Aikuiskasvatukseen ja -koulutukseen investoiminen}

On ymmärrettävää, että aikaisemmin, hitaan muutoksen kautena painopiste on ollut nuorten peruskoulutuksessa. Nykyisen nopean rakenteellisen kehityksen kautena se ei enää sitä ole. Koulutusuudistukset vaikuttavat vasta pitkän ajan kuluttua. Nuorten koulutukseen sijoittaminen antaa pikemminkin pitkän kuin lyhyen aikavälin tuloksia. Toisaalta aikuiskoulutukseen investoiminen, tapahtuupa tämä työpaikoilla tai niiden ulkopuolella, voi tuottaa jossain määrin välittömämpiä vaikutuksia. Aikuiset ovat yleensä, sen lisäksi että he kykenevät soveltamaan oppimaansa, innokkaita ja tehokkaita oppijoita.
Aikuisten työpaikka- ja työllisyyskoulutus on nopeasti lisääntymässä. Ollakseen kilpailukykyisiä eri maiden on varmistuttava siitä, että niiden työvoima kykenee sopeutumaan muuttuviin vaatimuksiin, suorittamaan monenlaisia tehtäviä, ylittämään ammatilliset rajat, ymmärtämään yrityksen laajemmat tavoitteet ja hankkimaan uusia tietoja ja taitoja, kun tilanne sitä vaatii. Tämä edellyttää hyvin järjestettyä kansallista aikuiskoulutusjärjestelmää.

Työpaikkakoulutus lisääntyy jatkossakin ja sen vaikuttavuutta pyritään parantamaan intensiivisesti. Euroopan maat pyrkivät jäljittelemään japanilaisten yritysten tarjoamaa laaja-alaista ja monipuolista aikuiskoulutusta. Uusien työntekijöiden perehdyttämiskoulutukseen kiinnitetään lisääntyvästi huomiota. Voimakkainta lisääntyminen on kuitenkin vanhojen työntekijöiden kouluttamisessa. Uusi teknologia edellyttää perusteellisia muutoksia sekä työprosesseissa että tuotantomenetelmissä. Enää ei riitä, että keskitytään vain muutamien avainhenkilöiden kouluttamiseen; kun uusi teknologia nopeasti lisääntyy, on yrityksen koko työvoiman tiedot ja taidot välttämätöntä saada ajan tasalle.

Koulutuksen laajentuminen ei kuitenkaan voi jatkua, ellei tehdä sopivia järjestelyjä kompensoimaan työntekijöiden ansionmenetyksiä. Tämän pitäisi johtaa pikaisesti sellaisten taloudellisten tukijärjestelmien lisäämiseen, jotka mahdollistavat palkallisen opinto-vapaan.

\section{Erityistarpeita}

Pienten ja keskisuurten yritysten ja alueellisten kehitystarpeiden pohjalta jatkuvasti lisääntyvä koulutuksen kysyntä korostaa yliopistojen tärkeää roolia.

Suurilla yrityksillä on mahdollisuus järjestää omaa koulutusta ja ainakin jossain määrin vaikuttaa julkiseen tukeen. Vaikka pienten yritysten lukumäärä lisääntyykin huomattavaa vauhtia - Italiassa niitä ilmoitetaan olevan 7.5 miljoonaa - ne eivät yleensä kykene kustannussyistä ja menetetystä työajasta johtuen järjestämään omaa koulutusta, eivätkä saa toivomuksiaan ja vaatimuksiaan julkisten viranomaisten tietoon. Tämä koskee erityisesti laajenevaa palve- 
lusektoria, jossa suurin osa henkilöstöstä on kouluttamatonta ja jossa suorittavan työn tilapäis- ja erillisluonne vaikeuttaa yhteistyötä koulutusjärjestelmän kanssa.

Aikana, jolloin yritysten rakenteellinen sopeutuminen johtaa nopeaan laajenemiseen toisilla aloilla ja alueilla ja heikentymiseen toisilla, ei alueellisesti kohdistetun koulutuksen arvoa voida liiaksi korostaa. Sosiaalisiin ja taloudellisiin strategioihin integroitua hätäkoulutusta tarvitaan lisääntyvässä määrin avustamaan kohteita, joissa kokonaisia teollisuudenaloja kuten kaivostoiminta tai laivanrakennus lopetetaan. Monet ihmiset on koulutettava kokonaan uusiin ammatteihin.

\section{Koulutuksellisesti huono-osaisten tarpeet}

Koska aikuiskoulutus laajenee pääasiassa tyydyttämään taloudellisia tarpeita, hallitusten on kiinnitettävä huomiota yleisten koulutusmahdollisuuksien oikeudenmukaiseen jakautumiseen. Jotkut ovat halukkaita rahoittamaan suoraan vain niitä ohjelmia ja opiskelijoita, jotka lupaavat taloudellista tuottoa.

Mutta eikö hallitusten tulisi rahoittaa laajasti huono-osaisten koulutusohjelmia? Huono-osaiset ovat useimmissa Euroopan maissa nopeasti kasvava alaluokka, johon kuuluvista monet ovat funktionaalisesti lukutaidottomia. Esimerkiksi Ranskassa Kansallinen tilasto- ja taloustutkimuksen instituutti osoitti eräässä raportissaan, että 37 miljoonasta aikuisesta 3,3 miljoonalla on suuria vaikeuksia lukea, kirjoittaa tai puhua ranskaa. Näistä 400000 ei osaa ollenkaan lukea eikä kirjoittaa. (1988).

Huono-osaisia on vaikea tavoittaa ja kallista avustaa. Kun heille tarjotaan opiskelumahdollisuuksia, ei ole varmuutta kannattavuudesta eikä ainakaan nopeasta hyödystä. Vain ne kansalliset ja alueelliset viranomaiset, jotka näkevät asian laajempana sosiaalisena ja oikeudenmukaisuuskysymyksenä, haluavat tukea huono-osaisten ohjelmia riittävästi. Käytännössä näitä ohjelmia voi olla vain paikallisella tasolla, sillä vain väestön enemmistön koulutustarpeet voidaan täsmällisesti tunnistaa, arvioida ja ratkaista.

\section{Erityiskohteet}

Kolme heikossa asemassa olevaa ryhmää tarvitsee erityishuomiota: (1) työelämään siirtyvät kouluikäisten lasten äidit, (2) yksinhuoltajat ja (3) ikääntyvät ihmiset.

Kodin ulkopuolelle työelämään siirtyvien kouluikäisten lasten äitien lukumäärä on jo nopeassa kasvussa useimmissa Euroopan maissa. Koska koulunsa jättävien nuorten ikäluokkien koko pienenee voimakkaasti ja koska työmarkkinoille syntyy tietyille aloille työvoimapulaa, syntyy suuri paine äitien paluulle työelämään. Kaikki työt eivät vaadi erityistaitoja. Monet työt, ehkäpä suurin osa, edellyttävät, että palaajat verestävät taitojaan tai hankkivat aivan uusia.

Lastenhoitopaikkoja, joiden kysyntä on jo nyt suurta, on niin ikään lisättävä, sillä vanhemmat voivat mennä kodin ulkopuolelle työhön vain, jos heidän lastensa hoito on järjestyksessä. Myös yksinhuoltajien lasten hoitopalveluksia tulee lisätä ja parantaa.

Eräs ensisijainen tulevaisuuden kysymys on, ovatko nyky-yhteiskunnan suuret ikääntyvien joukot taloudellisessa mielessä resurssi vai kasvava julkinen rasitus. Erityisesti korkean nuorisotyöttömyyden vuoksi on vuodesta 1976 lähtien näihin päiviin saakka ollut poliittisesti mahdotonta ajatella, että voitaisiin jatkaa työssäoloa lakisääteisen eläkeiän jälkeen. Näkymä lähestyvästä työvoimapulasta muuttaa täysin tilanteen ja tarjoaa yhteiskunnalle tilaisuuden välttää taloudellisen aktiviteetin romahdus.

Vaikka nykyistä eläkeikää ei enää laskettaisikaan, tulevaisuudessa lähes kaikissa Euroopan maissa työvoimaan kuulumattoman aikuisväestön määrä kasvaa, samalla kun aktiivisen työvoiman määrä laskee. Entistä pienempi määrä työssä olevia elättää suurempaa ja suurempaa määrää työn ulkopuolella olevia. Ilmeinen ratkaisu on sallia eläkkeelle siirtymisiän nostaminen tai tehdä se aikaisempaa joustavammaksi niin, että ihmiset voivat, ainakin osa-aikaisesti, työskennellä niin kauan kuin haluavat.

Erilaisen asenteen ja uuden politiikan omaksuminen ikääntyviä kohtaan vaikuttaa perinpohjaisesti kasvatukseen ja koulutukseen. Se 
merkitsee sitä, että vanhoja ihmisiä autetaan sopeutumaan heidän muuttuviin fyysisiin, taloudellisiin ja sosiaalisiin olosuhteisiin, tarjotaan heille mahdollisuuksia osallistua opintoihin, jotka on suunniteltu kaiken ikäisille eikä vain tietyille ikäryhmille.

\section{YLIOPISTOT JA AIKUISKASVATUS}

\section{Muuttuvat tehtävät}

Yliopistot ovat viime vuosina saaneet enemmän kuin kohtuullisen osansa siitä kritiikistä, jolla koulutusjärjestelmää on pantu yleisesti matalaksi. Niitä on syytetty löhöämisestä muusta yhteiskunnasta erillisten etuoikeuksiensa suojassa ja kykenemättömyydestä edistää tehokkaasti yhteiskunnan hyvinvointia. Olivatpa tällaisten syytösten perustelut mitä tahansa, viranomaiset ovat useimmissa maissa ottaneet yliopistojen rahoituksen ja toiminnan huolellisen tarkastelun kohteeksi. Yliopistot ovat puolestaan aloittaneet intensiivisen itsetutkistelun ja ryhtyneet tehtäviensä huomattavaan uudelleen arviointiin.

Tarkastelen vain niitä uudistuksia, joiden tarkoituksena on avata yliopistoa ulospäin yhteiskuntaan ja laajentaa aikuisten opiskelumahdollisuuksia.

Ensiksikin on omaksuttu aikaisempaa joustavampia rahoitus- ja organisointitapoja, ja näitä syntyy edelleen. Sen lisäksi, että eräät viranomaiset ovat vaatineet opiskelukiintiöitä aikuisille kuten Ruotsissa, yliopistot ovat lisääntyvässä määrin laajentamassa aikuisten opiskelumahdollisuuksia muuttamalla sisäänpääsyvaatimuksia ja lisäämällä joustoa kurssien järjestämisessä ja opintojen arvioinnissa. Toiseksi yliopistot ovat ottamassa vastuuta jo valmistuneiden lääkäreiden, lakimiesten, ekonomien, insinöörien jne. - jatkuvasta kouluttamisesta ja tarjoamassa lyhytkestoisia kursseja liike- ja virkamiehille ja muille ammattilaisille. Kolmanneksi yliopistot ovat panostamassa entistä enemmän erityisesti paikalliselta tasolta nousevaan hallinnon, liike-elämän ja teollisuuden käytännön ongelmia ratkovaan soveltavaan tutkimukseen.

\section{Kasvavat osallistujamäärät}

Tulevaisuuden avaintekijänä tulee olemaan väestön pieneneminen. Länsi- Euroopan maissa 18-vuotiaiden lukumäärä laskee 1990-luvulla keskimäärin 22 prosenttia. Vuoteen 2000 mennessä yliopistoikäisten määrä on vähentynyt vuosikymmenessä seuraavasti: Saksassa 45 prosenttia, Hollannissa ja Englannissa 30 prosenttia, Ranskassa ja Ruotsissa 15 prosenttia. Mitä tämä vaikuttaa yliopistoihin? Hyväksyvätkö ne väistämättömän supistumisen vai kykenevätkö ne säilyttämään nykyisen tai korkeamman sisäänoton tason?

Näyttää siltä, että nykyiset tai jopa korkeammat opiskelijamäärät on turvattu. Tähän on pääasiassa kaksi syytä. Yhteiskunnallisen ja poliittinen mielipide rohkaisee siihen, että entistä suurempi osuus koulunsa lopettavista haluaa jatkaa yliopistoissa ja tämä enemmän kuin vain kompensoi ikäluokan pienenemisestä johtuvan laskun. Toiseksi pätevien pyrkijöiden lukumäärä kasvaa.

Yksi seikka on varma: mikään maa ei halua yliopisto-opiskelijoiden määrä laskevan jyrkästi. Nykyisin ovat kaikki vakuuttuneita siitä, että yliopistoista valmistuneiden määrä tulee pitää korkeana. Kaikki tietävät, että Japanin huomattava taloudellinen menestyminen on yhteydessä korkean yliopisto-opiskelijoiden määrän kanssa. Korkeat opiskelijamäärät USA:ssa ovat toisena esimerkkinä: 50 prosenttia high schooleista valmistuvista jatkavat opintojaan. On myös merkkejä siitä, että enää ei panosteta yksinomaan nuorten jatko-opintoihin; koulunsa lopettaneita aikuisia rohkaistaan tutkinnon suorittamiseen lisääntyvässä määrin.

\section{Vastuu aikuiskasvatuksesta}

Tämä johtaa kysymykseen yliopistojen aikuiskasvatusvastuusta. Jotkut yliopistot jäävät elitistisiksi. Muutamat ovat omaksuneet täysin avoimen sisäänpääsyn periaatteen. Suurin osa haluaisi edelleen preferoida kokopäiväopiskelijoiden opetusta ja tutkimustyötä, mutta vastahakoisesti ne tunnustavat välttämättömyyden logiikan. Ne tarkistavat sisäänpääsyvaatimuksia, ottavat osapäiväopiskelijoita ja alkavat kehitellä 
uusia yliopiston ulkopuolisia toimintamuotoja ja laajentaa jo olemassa olevia. Uusien toimintamuotojen kehittäminen ja toimintojen laajentaminen perustuu seuraaviin havaintoihin.

Ensiksikin monet aikuiset eivät aloita yliopisto-opintoja, koska opiskelupaikkoja on niukasti, ja heille ei ole tarjolla apurahoja, ei siksi että he eivät täyttäisi sisäänpääsyvaatimuksia. On myös ilmeistä, että jotkut aikuiset alkavat vasta myöhemmin, koulun jo jätettyään, arvostaa akateemisten opintojen tarjoamia hyötyjä.

Toiseksi koska tieto lisääntyy eksponentiaalista vauhtia, ei kukaan voi valmistua lopullisesti tiettyä uraa varten. Tämän päivän opiskelija lähtee yliopistosta halliten vain alustavasti tietoaineksen; suuri osa tiedosta, jonka he saavat, voi vanheta hyvinkin nopeasti. Siksi on välttämätöntä, että he pitävät tietonsa ajan tasalla ja laajentavat taitojaan. Erityisesti sellaiset ammatinharjoittajat, kuten insinöörit, lääkärit ja arkkitehdit, joutuvat jatkuvasti lisäämään tietojaan osallistumalla täydennyskoulutukseen. Yliopistot eivät voi enää olettaa, että loppututkinnon suorittaminen merkitsee opiskelun lopettamista.

Kolmanneksi, kuten jo mainittiin, on välttämätöntä kouluttaa aikaisempaa enemmän naisia palkkatyöhön. Tarvitaan parempia palveluja, jotta aikuiset naiset voivat suorittaa ensimmäisen tutkintonsa tai muun pätevöittävän koulutuksen ja että saadaan yliopistotutkinnon suorittaneet naiset takaisin akateemisten opintojen pariin keskeytynyttä uraansa jatkamaan tai vaihtamaan se uuteen.

Lopuksi, mutta ei suinkaan vähiten tärkeänä perusteena on, että yliopisto-opettajien on oltava yhteydessä muuhun yhteiskuntaan ja että tämä toteutuu parhaiten opettamalla aikuisten jatkokoulutustilaisuuksissa. Opettajat hyötyvät itse yhtä paljon opiskelijoiden kokemuksista kuin heillä on annettavana oppilailleen.

Avainpäätelmä edellä sanotusta on, että järjestettäessä opetusta tulevaisuudessa yliopistojen tulisi antaa yhtäläinen paino sekä aikuisille - koko- ja osa-aikaopiskelijoille - että nuorille. Tämä ei tarkoita, että vain odotetaan avunpyyntöjä tai otetaan vastahakoisesti huomioon ulkoa päin tulevat vaateet, vaan että tutkitaan systemaattisesti nopean taloudellisen ja teknologisen muutoksen sosiaalisia seuraamuksia ja sitä, miten yliopistot voivat auttaa yhteiskuntaa käsittelemään niitä. On olemassa useita tapoja, joilla yliopistot voivat auttaa yhteiskuntaa, mutta ehkäpä arvokkainta on tarjota kattavia ja monipuolisia aikuiskoulutusohjelmia.

\section{Uudistuksia}

Uudistushakuiset yliopistot tarjoavat jo ohjelmia, joiden olennaisina elementteinä ovat seuraavat piirteet:

1) Arvosanoja voidaan suorittaa osa-aikaisesti opiskellen.

2) Jatko-opintoja voidaan suorittaa osa-aikaisesti.

3) täydennyskursseja työelämässä toimiville tutkinnon suorittaneille

4) ei-tutkintoihin johtavia kursseja ja erityisohjelmia:

- lyhyt- ja pitkäkestoisia kursseja ammattilaisille sekä yleissivistäviä kursseja

5) erityisesti kunnallisvaikuttajille suunniteltuja kursseja

6) aikuisopettajille ja -koulutussuunnittelijoille tarkoitettuja kursseja

7) osa-aikaopiskelua ja -opiskelijoita koskevaa tutkimusta; ja

8) yhteistyötä muiden tahojen kanssa varmistamaan, että yhteisössä on riittävät osa-aikaisen opiskelun mahdollisuudet.

\section{Täydennyskoulutus- keskuksien tarve}

Tänään monen yliopiston haasteena on, miten järjestää kattavat täydennyskoulutuspalvelut. Jotkut yliopistot voivat kehittyä orgaanisesti vastaamalla erilaisiin tarpeisiin ja päästä tilan- 
teeseen jossa, kuten monet valtionyliopistot USA:ssa, tarjoavat koko joukon erilaisia yliopiston ulkopuolelle suuntautuvia palveluksia. Mutta silloin, kun mikään yliopiston yksikkö ei ole erityisesti vastuussa ulkopuolelle suunnattavista palveluksista, ei tehdä mitään, tai se, mitä tehdään, on sattumanvaraista ja hajanaista. Ihanne olisi, että jokainen yliopisto omaksuisi aktiivisen täydennyskoulutuspolitiikan ja kehittäisi sen toteuttamiseksi tehokkaan yksikön. Käytännön ohjeeksi ja esimerkiksi sopii Wisconsin Universityn tunnettu slogan: "Kampuksen rajat ovat valtion rajat”.

Euroopan yliopistot ovat kaukana Wisconsinin mallista. Muutamilla yliopistoilla on osastoja tai laitoksia, joissa suunnitellaan ja hallinnoidaan täydennyskoulutusta; kun sellaisia on, ovat yliopistot kohdelleet niitä toisarvoisesti siihen nähden, mitä ne itse pitävät olennaisina tehtävinään. Tämä on ollut monen täydennyskoulutusosaston ja -laitoksen kohtalona. Kuitenkin vain erityislaitos voi taata hallinnollisen järjestyksen jatkuvuuden.

Tämä ei suinkaan merkitse sitä, etteikö myös yliopiston muiden yksiköiden pitäisi järjestää täydennyskoulutusta. Nyky-yhteiskunnan vaatimukset ovat niin moninaiset ja useiden yliopistojen rakenne on 1960-luvun laajentumisvaiheen johdosta tullut niin monimutkaiseksi, että ei ole järkevää kanavoida kaikkea yliopiston ulkopuolelle kohdistuvaa toimintaa tapahtuvaksi yhden yksikön kautta. Kaikkien aikuiskasvatukseen omistautuneiden yliopistojen ongelmana on, miten ylläpitää erillistä laitosta ja samalla varmistaa, että käytettävissä on merkittävä osa kaikista yliopiston opettajista.

\section{Ei vain hyödyn vuoksi}

Olen tässä esityksessä korostanut, että yhteiskunnan vaatimus aikuiskasvatukselle on tuottaa oikeaksi arvioitu määrä ammattitaitoista työvoimaa.

Tietysti olen tietoinen siitä, että teknologisten ja taloudellisten perusteiden pohjalta tapahtuva oppimistarpeiden tyydyttäminen on vain yksi aikuiskasvatuksen funktioista. Aikuiskasvatuksen pysyvä tehtävä on aina mahdollisuuden antaminen ihmisille tutkia asioita ja ratkoa ongelmia, joilla ei ole mitään välitöntä yhteyttä heidän päivittäisen työnsä kanssa. Keskittyminen vain työhön liittyviin koulutustarpeisiin muodostaa riskin laiminlyödä ryhmien ja yksilöiden yleisemmät opiskelupyrkimykset.

Olennaisen tärkeää on tarjota laajoja julkisia tai yksityisiä aikuiskasvatusohjelmia, jotka on suunniteltu edistämään ja rikastamaan koko yhteiskunnan älyllistä ja kulttuurista elämää.
Lybentäen suomentanut RAINER AALTONEN 